\title{
Experimental Program and Technical Assistance in Alpine Cheesemaker Huts of Friuli Venezia Giulia (Italy)
}

\author{
Simona Rainis $^{1}$, Ennio Pittino ${ }^{2}$, Giordano Chiopris ${ }^{2}$ \\ ${ }^{1}$ Crita S.c.a.r.1. - Research Center for Technological Innovation in Agriculture, Via Pozzuolo, Udine, Italy \\ ${ }^{2}$ Ersa - Regional Agency for Rural Development of Friuli Venezia Giulia, Via Del Montesanto, Gorizia, Italy \\ Email address: \\ s.rainis@libero.it (S. Rainis), ennio.pittino@ersa.fvg.it (E. Pittino), Giordano.chiopris@ersa.fvg.it (G. Chiopris)
}

\section{To cite this article:}

Simona Rainis, Ennio Pittino, Giordano Chiopris. Experimental Program and Technical Assistance in Alpine Cheesemaker Huts of Friuli Venezia Giulia (Italy). Agriculture, Forestry and Fisheries. Vol. 5, No. 2, 2016, pp. 18-29. doi: 10.11648/j.aff.20160502.12

Received: February 11, 2016; Accepted: February 24, 2016; Published: April 6, 2016

\begin{abstract}
In Friuli Venezia Giulia (Italy), traditionally transhumance and mountain grazing characterize the activity of zootechnic breeders during the summer period. In these alpine pastures ("malga") there are typical cheesemaking huts (called "casere") with an important activity of dairy productions that represents an important sector of the agriculture in this Region. The main products are alpine cheeses and smoked ricotta cheese, with flavors and aromas unique and inimitable, due to the old autochthonous recipes, the "art" of the cheesemakers and the environmental conditions. In the present paper, the experimental area taken into account is represented by the Friulian mountains in Italy. The trial consisted in the technical assistance related to the productive pathways of the alpine cheese and alpine ricotta cheese, performed by ERSA - the Regional Agency for Rural Development of Friuli Venezia Giulia (Italy). 800 dairy operations, 418 of mountain cheese and 382 of smoked ricotta cheese respectively, were followed in 20 productive units. Amount of milk transformed, acidities of the milk and whey, temperatures, durations of the processing and microclimatic parameters were registered. Suggestions and advices were given to the cheesemakers in order to improve the quality of the products. Analyzing the period taken into account, it can be observed that important goals along all the productive pathway were obtained. This type of experimental and technical assistance can be a good practice for all the farms in marginal areas.
\end{abstract}

Keywords: Alpage, Alpine Cheese, Alpine Ricotta Cheese, Marginal Areas Development, Mountain Agriculture

\section{Introduction}

Pastures of Friuli Venezia Giulia are situated at the extreme Eastern edge of the Italian slope of the Alpine arc. The farming landscape system in this region is characterized especially by livestock husbandry (almost the $77 \%$ of the agricultural holdings) of bovines and ovi-caprines. In this marginal area, traditionally, transhumance and mountain grazing mark the activity of zootechnic breeders during the summer period, thanks to the fact that this mountainous portion of Italy presents a significant climatic, geographic and agricultural diversity. For definition, an alpine pasture ("malga") is a holding where livestock are moved over summertime from the lowland permanent farms to exploit the meadows, as shown in Figure 1.

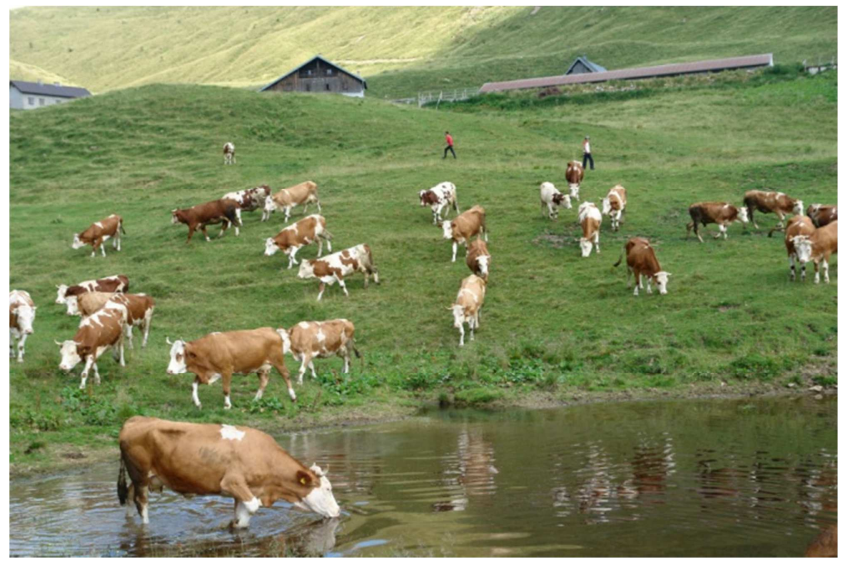

Figure 1. An example of "malga", productive unit in the Alps during the summer. 
In these high altitudes there are traditional cheesemaking huts (called "casere") so there is an important activity of cheesemaking without the need to carry the milk back down to the valley [1]. This seasonal dairy production represents an important sector of the agriculture in this Region [2], in fact this peculiar activity constitutes a fundamental train for the local farmers, because it allows the social and financial progress of the autochthonous population and in general it ensures the tutelage of their identity and culture patrimony. In this delicate and fragile historical moment, the new paradigm for a sustainable development emphasizes the role of extensive breeding and low impact and eco-friendly activities as the alpage. In these specific areas, the mountain grazing and all the activities related to it contribute to preserve and also to exploit the peculiarity of the landscape and its aesthetic value, enhancing the recreational-ecological quality of the surroundings and its tourist appeal [3]. The alpiculture favorites the development of marginal areas, the production of safety food and environmental protection [4]. It is evident that the supporting of the activities that take place in this mountain productive units represents the tutelage of the typical products, the increasing of the farming profitability and the inclusion of new young strengths actively committed in the developing of their future [5].

Centuries of old traditions and methods insure that alpine cheeses and smoked ricotta cheese are unique from other types of similar products. Their flavors and aromas are typically described as nutty, fruity, spicy, floral, herbal, grassy and/or buttery. These inimitable tastes and smells are created by the skilled hands of the cheesemakers, the traditional recipes perfected over generations and the highquality, butterfat milk from cows grazing mainly on lush, seasonal plants and grasses found up and down the mountainside [6]. Since the animals are fed almost on exclusive mountain pastures with little microclimates, each product tastes different than the next, due to the strong alpine herbs that grow differently in every area. Furthermore the regions developed their own unique style due to herd sizes, remoteness and local preferences [7].

In this context, a relevant experimental design of technical assistance for the dairy sector in alpine lands is performed form the 2002 by Ersa, the Regional agency for rural development in Friuli Venezia Giulia (Italy). This action consists in several technical visits in the cheesemaking huts in order to follow the processing pathway of dairy production, ensuring a high level consultancy. The suggestions and advices are related chiefly to milk quality and productive technology. Together with the farms, it is an important moment also of evaluation of the estate and functionality of all the productive unit, of the animal welfare and so on. In every visit, they also register the productive and technological parameters (as the quantity of processed milk, the acidity, the temperatures, etc.).

The aim of the present paper is to present an overview of the data collected during these 14 years of assistance, in order to describe the traditional modality of dairy production in the alpine pastures of Friuli Venezia Giulia (Italy) and to describe the actual trend of this compartment.

\section{Methodology}

The project area taken into account is situated in the Friulian mountains, an Italian region.

In the present work the result of 14 years of experimental activity related to the productive pathways of the alpine cheese and alpine ricotta cheese is presented. This technical assistance was performed by the technicians of ERSA - the Regional Agency for Rural Development of Friuli Venezia Giulia (Italy). The joining to this support program is voluntary and it is open to all the cheesemaker huts of the area. 800 dairy operations, 418 of mountain cheese and 382 of smoked ricotta cheese respectively, were followed in 20 productive units.

For each one, apposite technical sheets were filled up, in order to note down the key parameters and possible criticisms during the processing as dairy products (Annex 1 and 2).

The acidities were registered by the employment of an acidimeter, with the Soxhlet-Henkel method and expressed in ${ }^{\circ} \mathrm{SH} / 50 \mathrm{ml}$.

The microclimatic parameters were monitored by an hygrometer and a thermometer, expressed respectively in \% of relative humidity and in ${ }^{\circ} \mathrm{C}$. In the case of the measurement of a trend, it was employed the logger, to determine these values at determinate intervals.

The concentration of brines were measured by a densimeter and expressed in the scale of Baumé ( $\left.{ }^{\circ} \mathrm{Bé}\right)$.

In this contribution, to stress out how the compartment is modifying, average data of the main parameters from 2002 to 2015 were taking into account. In particular, the comparison between the 2002 (the year of the begging of the experimental period), the 2009 (considered the mid-term) and the 2013, 2014 and 2015 (the last ones, that allows to observe how the present situation is, if there are some stabilizations and where are the possible ameliorate margins for improvement) was chosen to be explained.

All the collected data were then elaborated, to have a clear and exhaustive framework of the typical productions methodology. It was also possible to evaluate the evolution of the sector during the years.

It was performed using SPSS for Windows (version 7.5.21, SPSS Inc., Chicago, IL). Normality of data distribution and homogeneity of variance were tested using Shapiro-Wilks test. Data were also processed by principal component analysis carried out using The Unscrambler X version 10.2 (Camo Software AS, Oslo, Norway). Data were mean centered, variables were weighted with $1 / \mathrm{SD}$, and the full cross-validation method was used.

\section{Results and Discussion}

\subsection{Dairy Production}

The following data are referred to the dairy production, from the raw material collection till the final storage of 
cheese and smoked alpine ricotta (Figure 2). All these steps can affect considerably final result of the processing.

As regards the daily average amount of milk transformed, it can be observed that the medium size cheesemaker huts are the predominant (for example in 2015 they represent the $53 \%$ of the total productive units). Small size ones reach the $30-38 \%$, quite constant in all the period analyzed. The larger typologies showed a decreasing trend $(19 \%, 22 \%, 20 \%, 34 \%$ and $14 \%$ respectively in 2002, 2009, 2013, 2014 and in 2015) (Figure 3).

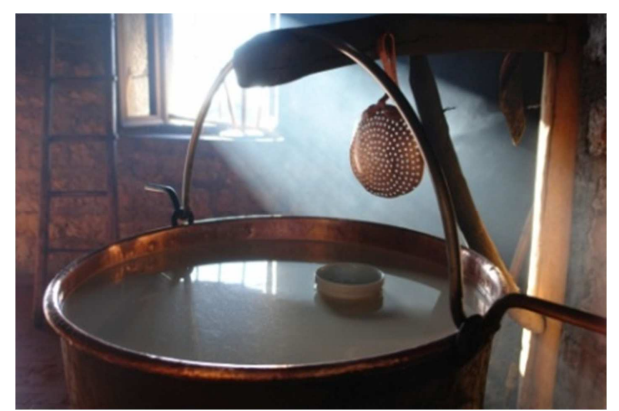

Figure 2. Milk in the boiler before the starting of the processing steps.

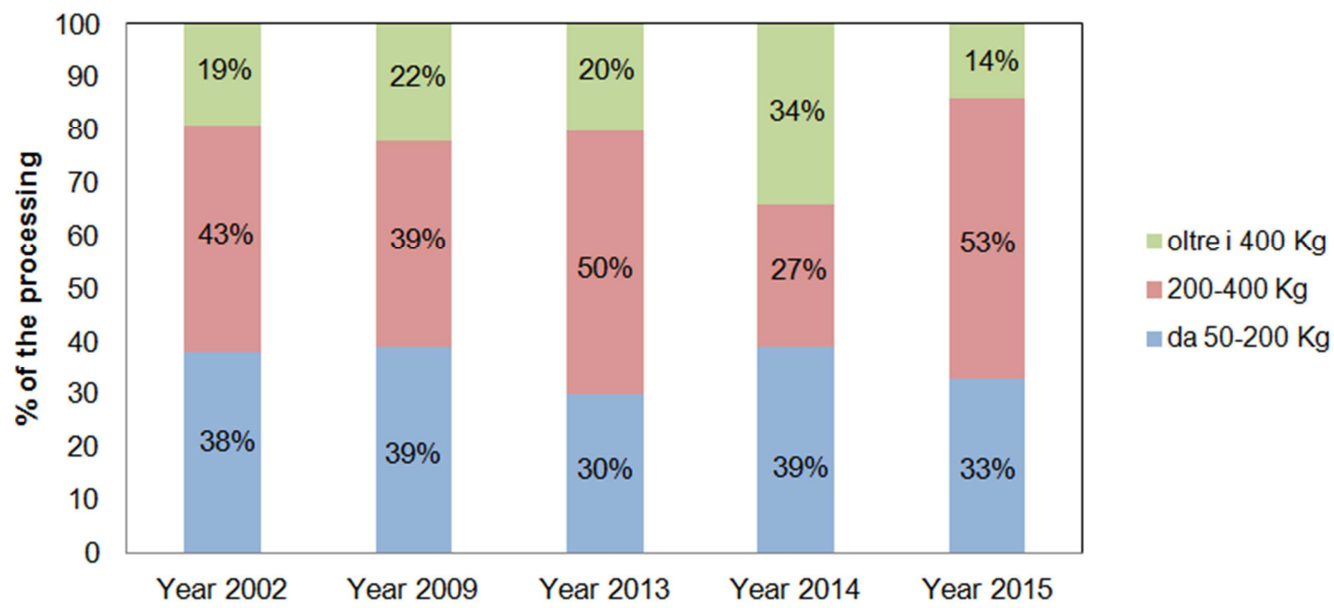

I modify the format of the graphs

Figure 3. \% of processing divided by the productive dimensions (comparison between years 2002-2009-2013-2014-2015) (P<0.05).

This values reflect perfectly the situation of the downhill farms. In fact, in Friuli Venezia Giulia, the dimensions of the agricultural holdings are year by year more oriented towards the medium size [8].

Particular attention was paid towards the rearing system and animal welfare. The herds were always suggested to control the sanitary situation of their cows before stocking the alpine meadows, in order to avoid the presence of ill animals that could affect the quality of milk. Following an ancient motto that says "a good cheese starts from the stable", a part the importance to avoid dairy cows with mastitis, the milking processing must be absolutely done with the maximum care, from the hygienic and physiological point of view. A preliminary work consists in the filtration of the milk that can allow the reduction of the largest part of contamination. An important step then is the storage of the milk of the previous days, that must be done considering especially the modality of the raw material cooling and the containers employed for this delicate phase. The cheese makers were always encouraged to maintain milk at a temperature between 8 and $14^{\circ} \mathrm{C}$, collecting it in bins perfectly sanitized and sealed. In the investigated farms, actually not always the storage temperatures of milk were respected, with obvious negative effects on the cheese production. The same attention should be put also for the storage rooms, that have to be always clean and tided up.

The acidity of fresh milk, of stored one, of their mix in the boiler, of whey after the curd milling and of final whey were check out [9]. This parameter allows the evaluation of the sanitary estate of the cows, the freshness of the raw material, its possible alteration, its maturation level and its attitude to the dairy transformation. Variations in organoleptic qualities are mainly due to technological factors and among them to the kinetics of acidification during cheesemaking, that can characterize a so-called disgenesic milks (low acidity, slow and difficult coagulation, low acidification rate and inadequate creaming activity).

In Figure 4 it is shown the comparison of the acidities measured in storage milk. In 2002, the average value observed was $4,01^{\circ} \mathrm{SH} / 50 \mathrm{ml}$, the following years were $3,34^{\circ} \mathrm{SH} / 50 \mathrm{ml}, 3,38^{\circ} \mathrm{SH} / 50 \mathrm{ml}, 3,47^{\circ} \mathrm{SH} / 50 \mathrm{ml}$ and $3,48^{\circ} \mathrm{SH} / 50 \mathrm{ml}$ respectively. As regards the acidity in the fresh milk (data not shown), the values were almost constant for all the years taken into account and it was about $3,40^{\circ} \mathrm{SH} / 50 \mathrm{ml}$.

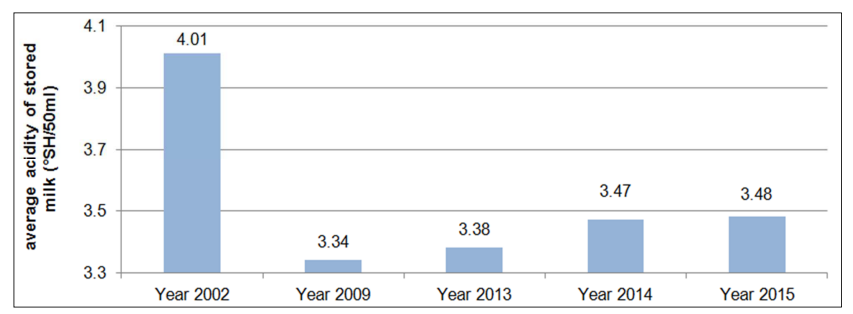

Figure 4. Acidity of the stored milk (comparison between years 2002-20092013-2014-2015) $(P<0.05)$. 
Throughout the amelioration of the sanitary estate of the herd and the more attention paid towards the quality of the milk (first of all during the storage phase of the raw material), taking into account the suggestions given by the ERSA technicians, it was possible to get the ideal values for this parameters $\left(3,5 \div 3,9^{\circ} \mathrm{SH} / 50 \mathrm{ml}\right)$ for the dairy transformation $[10,11]$.

The cheese makers were helped also to learn the use of the instruments for a preliminary milk evaluation, as the acidimeter, the $\mathrm{pH}$-meter (this instrument was introduce just in the two last years) and the "Leucocytest Roger Bellon" (the California Mastitis Test), which is useful for an early evaluation of the possible presence of mastitis in the herd, to attend immediately on the infect and to exclude the not suitable milk. They were encouraged to register all the values by themselves, in order to create a personal archive very useful to improve further processing [5].

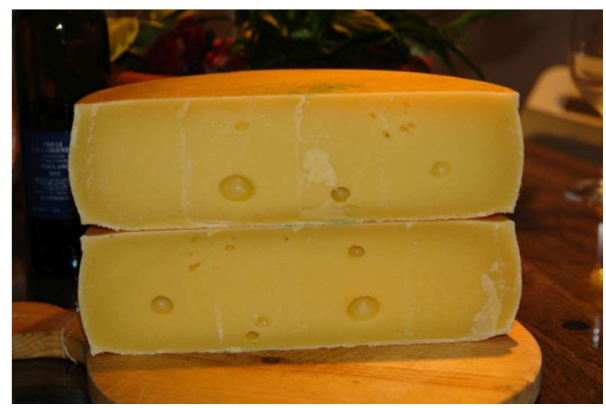

(local name: formadi di mont, Figure 5)

Figure 5. Typical autochthonous alpine cheese.

A very interesting element to be considered, especially for its relevant ecological impact, is the type of combustible material employed during the dairy processing. The utilization of wood in this alpine structure was almost the $76 \%$ in the 2002 , while this percentage unfortunately decreased to $69 \%, 65 \%, 56 \%$ and $69 \%$ respectively in 2009 , 2013, 2014 and 2015, with in parallel, obviously, the increment of the use of other synthetic fuels. This choice has a great relevance from the quality of the products, but also it is important for the economic and environmental point of view. In fact, the heating by wood contribute to impart to cheese and ricotta a unique bouquet of tastes, smells and perfumes, emphasizing the particular style of the Alpine cheesemaker who has produced. There are also implications on the biodiversity of the surroundings, because the collecting of firewood implies a care of the forest. This activity is considered precious and necessary for the tutelage and wise control of the mountain land. Last but not least, the natural resource permits a saving from the monetary point of view $[12,5,13]$.

The modality of typical dairy processing in alpine chalets are described below.

\subsection{Alpine Cheese}

The autochthonous productive pathway that characterizes the dairy tradition in this Region is shown in Figure 6.

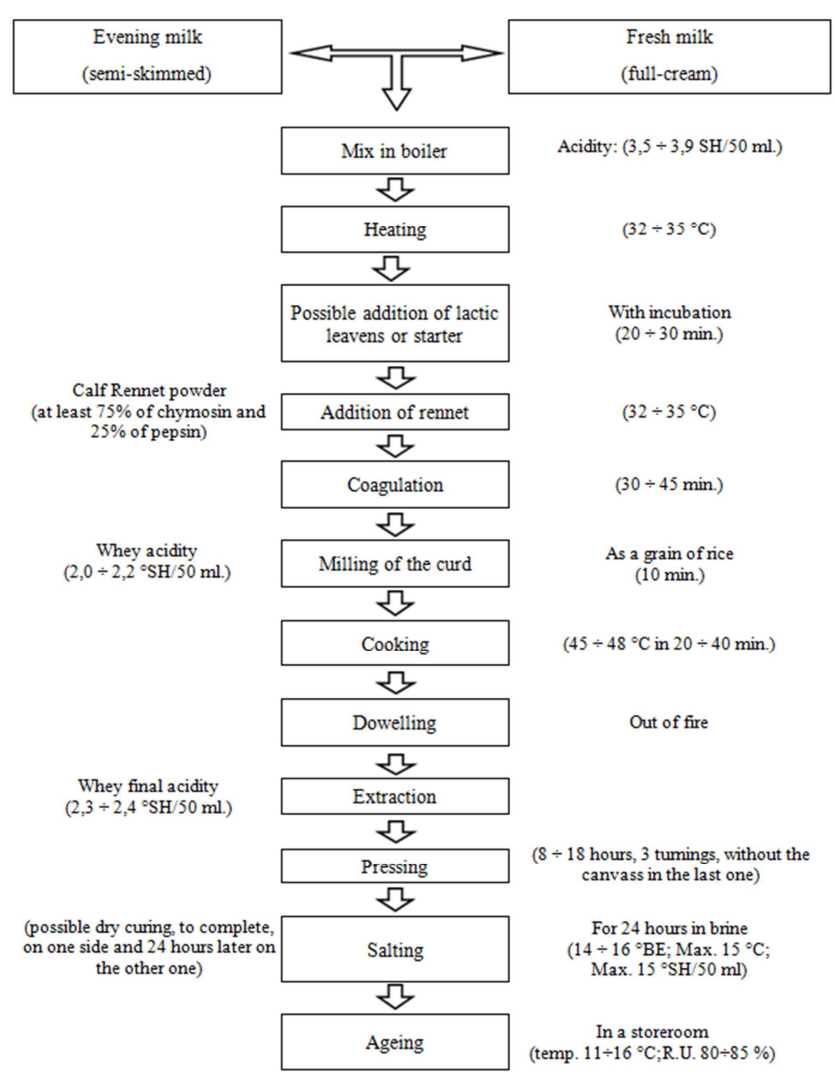

Figure 6. Technological diagram for the alpine cheese.

Own characteristics of this alpine cheese include:

- usually made from raw cow's milk heat treated (cooked), but not fully pasteurized;

- a semi-firm to hard texture with a dense paste;

- natural brushed/rubbed rind;

- large sized wheels;

- often presence of holes or "eyes". [6].

Lucey et al. [14] observed that the "art" or "science" of cheesemaking, that affects the physical properties of cheese (i.e., body/texture, melt/stretch, and color), is all about managing five key factors: initial milk composition, rate and extent of acid development, moisture content, curd manipulation and maturation conditions.

The cheese ripening is always affected by the interaction between milk (specific) and the traditional technology applied to the transformation process (non-specific). Also, the environment can be quite definite and not reproducible. The factors of typicality are:

- species and/or breed (genetic factors);

- the general environment and the pedo-climatic conditions;

- animal management system and feeding (that influence the protein and fat content, renneting properties, fatty acid composition and other chemical flavors);

- milk treatments and processing;

- the original microflora;

- the ripening procedures. [15].

This particular environmental obviously has a great influence on the sensory quality of dairy products, as 
confirmed by Martin et al. [16]. In particular, the botanical composition of the pasture have been recognized as a factor in flavor enrichment of cheese not only per se, as terpenes, sesquiterpenes etc., but also for compounds of microbial origin. Several studies have shown that the floristic diversity of grazed herbage can influence the sensory characteristics of raw milk cheese, especially for the direct or indirect effect of a complex blend of volatile compounds present in the different grass species [17]. Going into deep, Dovier et al. [18] underlined the differences between lowland and highland cheese, while Coloumb et al. [19] investigated also the positive correlation between the composition of fodder consumed by the cow and the altitude at which the cow grazes.

The renneting properties, as well as its clotting time, the coagulum strength and the syneresis rate are of major importance for the rheological characteristics of curd and then for the chemical-physical and structural properties of cheese. They influence whey drainage, which affects the moisture content of the curd, fundamental for the appropriate start of the cheese ripening processes, which are in turn linked to fermentation activity [20, 21].

The absence of the pasteurization ensures the maintenance of the incomparable fragrance of smells and tastes that the surrounding environmental of alpine pastures confers to the crude material. In these types of dairy products, it is essential to keep unaltered the constitutive microflora, with various microorganism of different species and with distinctive features. It can be affirmed that a major factor of success is the correct management of bacteriological traits, because, as reported by Agabriel and colleagues [22], the characteristics of ripened cheeses depend both on the cheesemaking technology and on the chemical and bacterial composition of milk. The microbes are able to multiple themselves actively, acidify and produce important substances that confer the desired flavor. Furthermore, these peculiarities could be exalted with the employment of the natural lactic leavens during the curdling, that don't modify the typical characteristics of milk, enhancing the differences and the authenticity among the productive units. This can be useful also in the case that the raw material presents microbiological, chemical or physical imbalances. In particular, the natural lactic leavens are used to:

a) increase the initial acidity of milk and to allow the curd to acidify. The measure of the ${ }^{\circ} \mathrm{SH} / 50 \mathrm{ml}$ value of the raw material determines the quantity of natural lactic leavens to be employed;

b) prevent coliform bacteria, since, being rich in lactic acid bacteria, they hinder the development of these unwanted microbes and limit the formation of tiny holes in the texture of the product;

c) modulate the fermentation and reduce defects in cheese [23].

Actually, in the last years, there is an increasing trend to employ industrial starters. In fact, in 2002, the $6 \%$ of the cheese makers used a synthetic starter, while the $42 \%$, the $49 \%$, the $47 \%$ and $31 \%$ were the data observed in the following years taking into account (Figure 7). The tendency for the natural lactic leavens was: $9 \%, 26 \%, 14 \%, 30 \%$ and $38 \%$ (always considering the years 2002, 2009, 2013, 2014 and 2015). The technicians always encouraged the cheese makers towards an own production, even if it requires time, precision and a particular accuracy (and this is the reason why a lot of producers tends to prefer the industrial ones, that are ready to be employed), because it is the only way to have a guaranty about the peculiarity and authenticity of the product. Furthermore, the group of Franciosi et al. [24] stated that the use of commercial starters in raw milk cheeses may modify the characteristics of the cheese microbiota, in particular lowering their biodiversity.

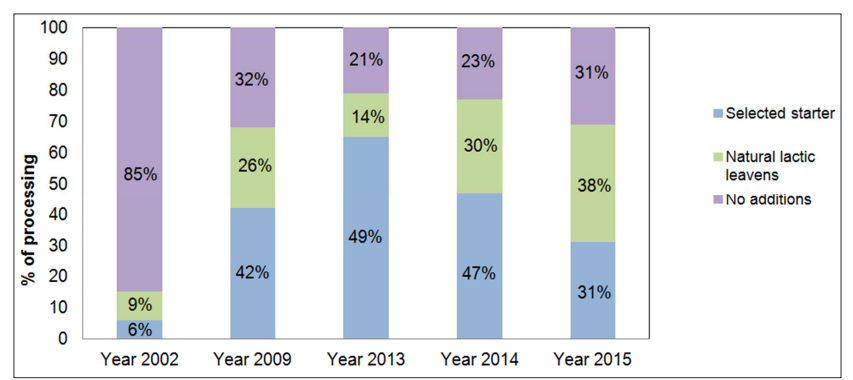

Figure 7. \% of productive units that employs different starters (comparison between years 2002-2009-2013-2014-2015) $(P<0.05)$.

The microbiome's role is also related to food safety and to health issues. Many of the bacteria that can be found on the rind prevent the spread of potentially dangerous pathogens by excreting inhibitors against them, such as listeria monocytogenes [25]. Other undesired germs can be recognized pathogens like Brucella spp., Staphylococcus aureus, Myobacterium tubercolosis, some Enterobacteriaceae, etc.; those that are unsuitable for cheese production like clostridia spores or simply competitors for the desired lactobacillum activity. For this reason, in order to optimize the bacterial quality, the cheese maker were suggested to respect the procedures of prophylactic and hygienic means of eradicating human transmissible diseases, to ensure the minimization of the animal fecal contamination and to guarantee the cleanliness in the milking plant and of the cheesemaker hut. The first reduction in active bacteria and spores can be successfully obtained through the physical effect of fat globules rising during natural creaming [21].

A general amelioration of the health and sanitary aspect was allowed also by the modernization of the milking process, with the introduction of small milking parlors directly on the pastures.

Going into deep of the technological stages, it is worth of consideration the size of the curd after the milling. It can be affirmed that gradually, from 2002 till 2015, the dimensions were reduce as a rice grain (data not shown). This dimension was strongly recommended during the technical visits because it allows to decrease the internal humidity of the cheese, thanks to a higher level of extraction of the whey. In this way, it is facilitated the further phase of the storage, in fact, there are less molds and it is preserved best physical 
parameters of the cheese wheels in the storage room.

Precise instructions were given about the timing and the temperatures to be respected during all the processing. In the comparison of the 5 years examined, the duration of the total processing in the boiler has reduced (from 107 minutes in 2002 to 93 minutes in 2015, as reported in Table 1). This aspect has an important advantage, because with a shorter manufacture the acidity of the whey can be contained, enhancing the following preparation of the ricotta cheese (that employs the residual whey of the previous processing of the cheese). A brief processing time allows also more free time for the cheese maker that can focus on the care of the subsequent steps as for example the pressing of the cheese [13].

In general, as it can be observed in Table 1, the average value registered respected the reference range.

Table 1. Average duration of the total processing pathway (min.) (comparison between 2002-2009-20013-2014-2015) (P<0.05).

\begin{tabular}{|c|c|c|c|c|c|c|}
\hline Technological parameters & 2002 & 2009 & 2013 & 2014 & 2015 & Reference range \\
\hline Temperature of calf rennet powder addition $\left({ }^{\circ} \mathrm{C}\right)$ & 34.6 & 34.8 & 34.5 & 34.6 & 34.9 & $32.0 \div 35.0$ \\
\hline Duration of the coagulation (min.) & 41 & 37 & 34 & 35 & 34 & $30 \div 45$ \\
\hline Duration of the curd milling (min.) & 11 & 13 & 15 & 14 & 13 & $10 \div 15$ \\
\hline Duration of the curd heating ( $\min$. ) & 30 & 27 & 25 & 23 & 24 & $20 \div 40$ \\
\hline Duration of the doweling (min.) & 24 & 23 & 22 & 26 & 22 & $15 \div 30$ \\
\hline Total duration of the processing (min.) & 107 & 101 & 98 & 98 & 93 & $90 \div 110$ \\
\hline
\end{tabular}

In the dairy technology, the modality of salting has a prominent role, in fact, it:

- completes the whey extraction,

- enhances the conservation of the final product,

- delays the acidification and the microbial colonization,

- favorites the rind formation,

- stimulates the protein solubilisation,

- confers the perfect flavor.

This step consists in dipping the cheeses in brine, made by a mix of water and salt. For this reason, this solution must be constantly monitored in order to avoid its degradation and fermentation, caused by the contamination with impurities and whey. These undesired processes are triggered by high temperatures. As Ponce De Leon-Gonzalez et al. [26] observed, this process requires a careful monitoring of the saturated solutions to obtain cheeses of good quality. During the experimental trial, the parameters of acidity ( ${ }^{\circ} \mathrm{SH} / 50 \mathrm{ml}$ ), salt concentration $\left({ }^{\circ} \mathrm{Bé}\right)$ and temperature $\left({ }^{\circ} \mathrm{C}\right)$ were always registered in the appropriate tubs of the brine. In particular, the acidity should be under the value of $15^{\circ} \mathrm{SH} / 50 \mathrm{ml}$ and salt concentration has to be in the range of $14 \div 16^{\circ} \mathrm{Bé}$, otherwise it is urgent to renew the brine. Furthermore, the temperatures of the solution must be kept under the $15^{\circ} \mathrm{C}$ and the ratio among the volumes of cheeses and salt concentration must be 1:5. In the course of the surveys, sometimes, the data observed were not satisfying the required value for an optimal salting phase, affecting seriously the final quality of the cheese. So the technicians tried to stress out the importance of caring about this important step of the dairy process, in order to avoid a brine that can confer to the product unpleasant smells of ammonia, ruin the rind and bring it an unusual color $[27,28]$.

The last phase of the processing consists in the storage that is performed in appropriate maturing warehouses (known as "celârs"). In the past, some building reconstructions or some ex novo stores weren't projected respecting the ideal features for an optimal cheese stocking phase. Traditionally, this room was oriented towards the North, at the basement and with thick walls made up by rocks and lime to guarantee the following conditions:

- constant temperature and humidity, due by a thermohygrometric exchange, also during very high thermal day/night temperature gap;

- a correct ventilation, throughout the windows wisely provided.

During the summer 2014, two loggers were simultaneously settled down in order to compare the microclimate parameters in a traditional store and in a modern one. Figures $8 \mathrm{a}$ and $8 \mathrm{~b}$ show that, in the typical building (red line in the graph), the internal conditions are better for cheese storage because there are no sudden variations of temperature and humidity, as observed, instead, in the new one (blue line). The tendencies noted were analogous to previous measurements done in 2004, with the same technique and in similar conditions (data not shown). Abrupt modifications of the values enhance the development of defects in the cheese [29]. In the structures with this type of inconveniences, it was suggest to install a dehumidifier or a conditioning system and to manage the opening of the windows to assure a good level of ventilation.

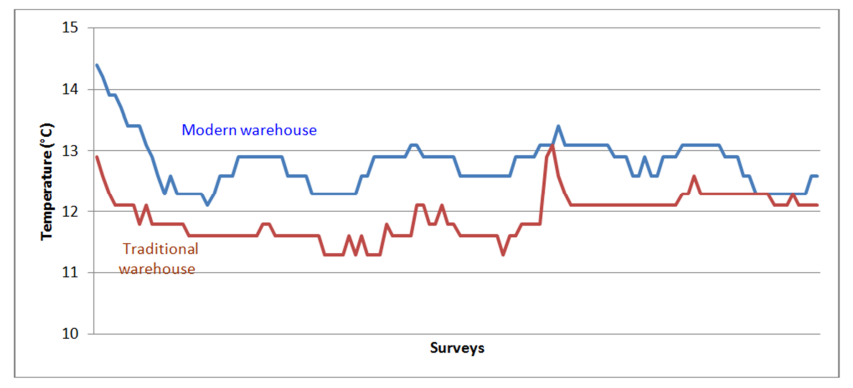

Figure 8a. Comparison of the thermal pattern observed in two warehouses (118 surveys in 5 days). 


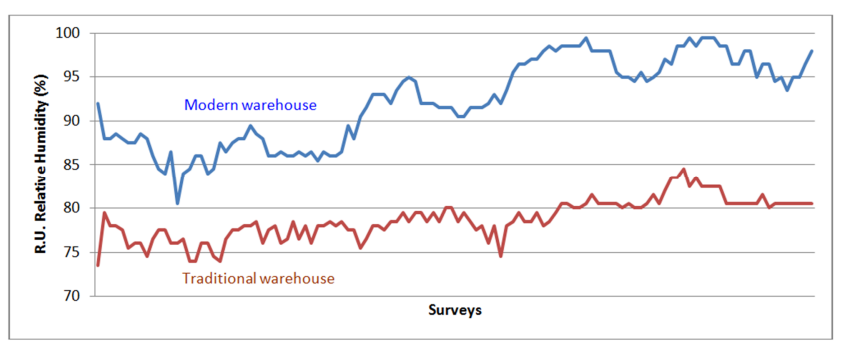

Figure 8b. Comparison of the hygrometric pattern (R.H. \%) in two warehouses (118 surveys in 5 days).

\subsection{Alpine Ricotta Cheese}

The second dairy product is the alpine ricotta cheese that is considered traditional because it has a documented history of more than 25 years. It symbolizes a style of cooking using autochthonous flavors of this Region [5]. In Figure 10, it is exemplified the technological diagram for this production. The whey, resulted from a previous cheese processing and still rich in some proteins, is flocculated with the addition of an acidifier. A further heating is necessary to curdle the mixture into a suspension of finely divided curd particles and to allow the fixture to stand while the curd particles rise to the surface. The curd is skimmed off by hand ladling into a suitable receptacle (traditionally canvass bags), as residual whey is drained off below them, to drip. The Ricotta curd is very delicate and will readily disintegrate and re-mix with the residual whey body if subjected to shock from rough handling during ladling. The following steps are the pressing, the salting and the smoking one.

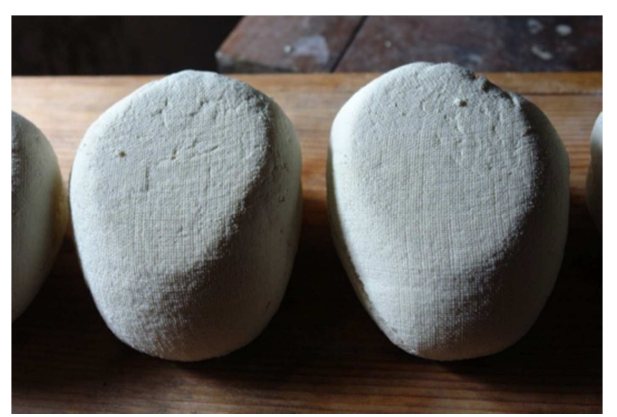

(traditional name: scuete fumade di mont, Figure 9)

Figure 9. Typical autochthonous alpine ricotta cheese.

\section{Technological diagram for the alpine ricotta cheese}

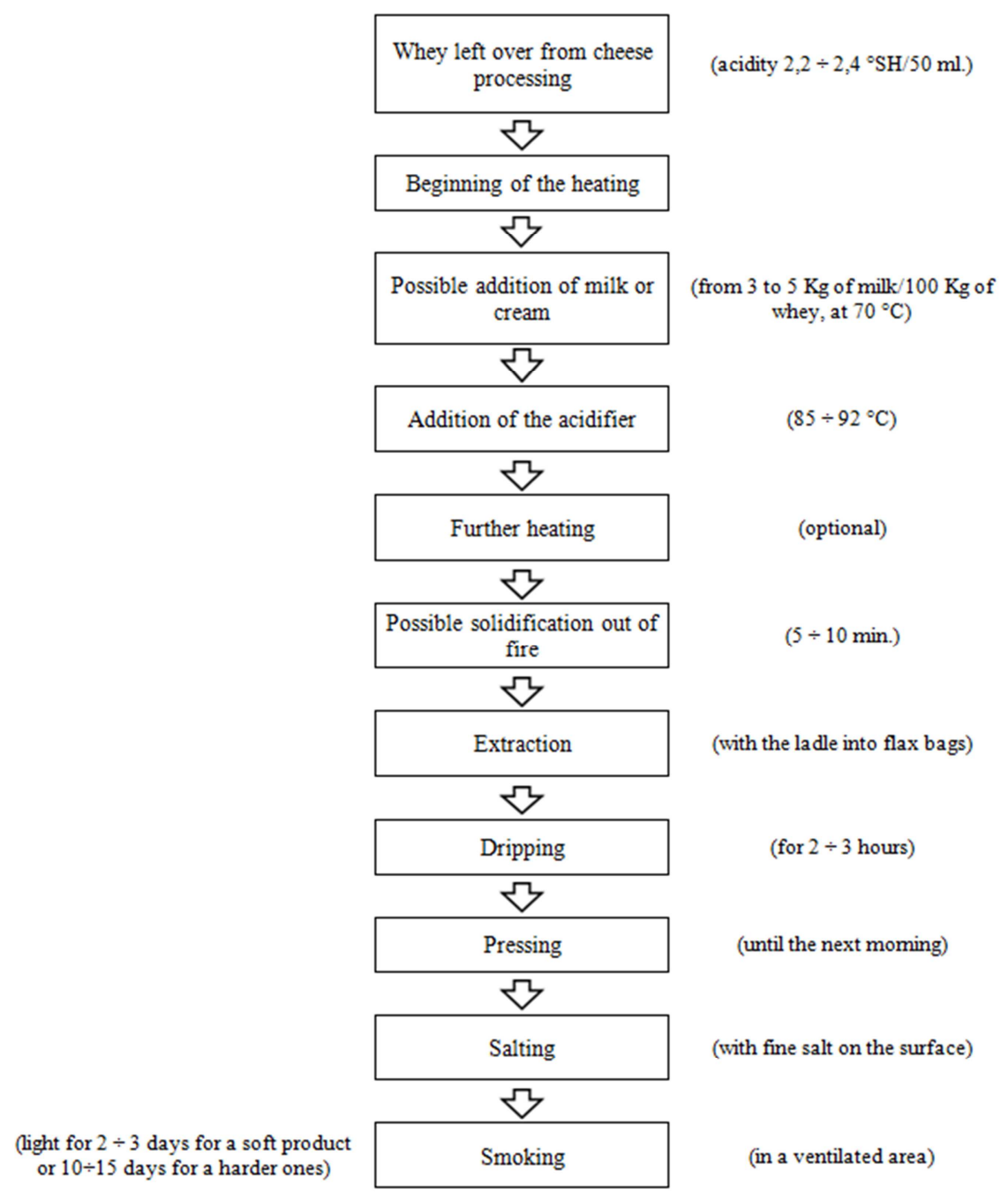

Figure 10. Alpine ricotta cheese. 
During the technical visits, all the values were registered in the schedules (Annex 2).

A very important aspect is the use of the acidifier. During the years the habits had some modifications. In 2002 the cheese makers mainly employed preferably magnesium sulfate $(65 \%)$. The $16 \%$ opted for the citric acid, while the $19 \%$ of them used some different products (referred as other in the Figure 11) that are related to a cultural heritage or a family tradition (for example: the vinegar or the siç, a particular mix of whey, beech bark and sorrel leaves). Analyzing all the experimental period, it can be observed the rise of the citric acid (from $16 \%$ in 2002 to $33 \%$ in 2015) and the reduction of magnesium sulfate (from $65 \%$ in 2002 to $38 \%$ in 2015). Furthermore, in 2009, there was the introduction, in some productive units, of a new industrial compound called "Sali mix". This substance is becoming more and more present, in fact, the \% of the processing utilizing it increased from $5 \%$ to $17 \%$ in 2002 and 2015 , respectively.

During the trial program, some recommendations were provided about the correct way of employing the acidifiers, their dose, the ideal temperature at which adding them. These aspects are essential to obtain a high quality ricotta cheese.

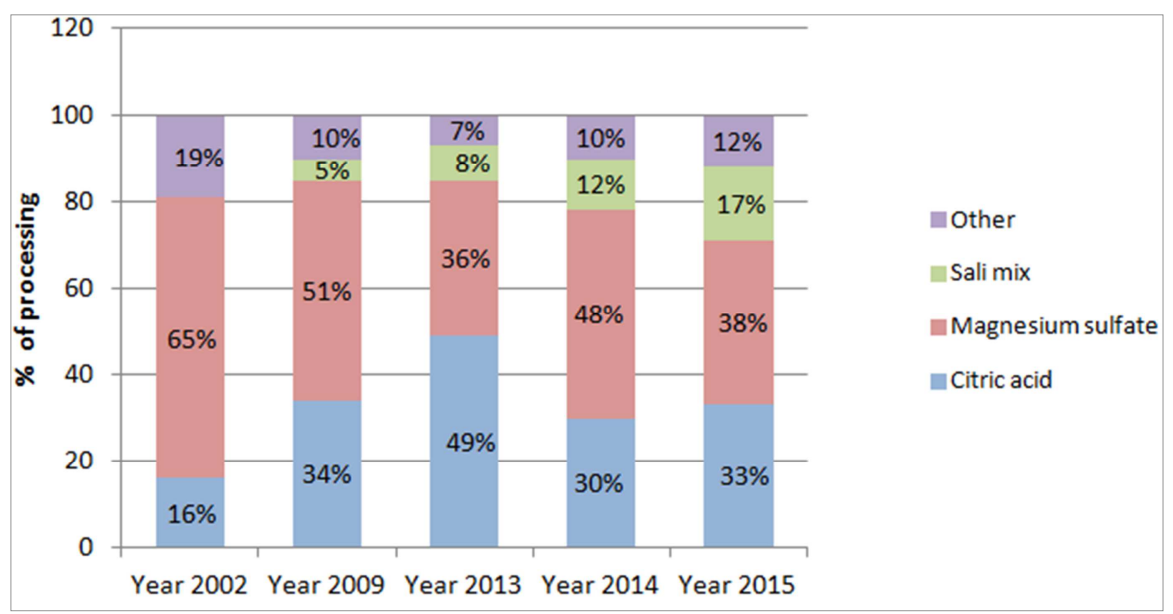

Figure 11. Type of acidifier employed for alpine ricotta cheese processing (comparison between years 2002-2009-2013-2014-2015) (P<0.05).

Considering the technique of adding milk, cream or buttermilk to the whey, it can be pointed out that also in this case there were evident modifications in the custom and practice of the cheese makers. In 2002, the $93 \%$ of them employed the whey pure to produce this dairy. Year by year, they tended to enrich the solution with milk, cream or buttermilk (as reported in Figure 12). In 2015, buttermilk was also mixed during the productive pathway of the alpine ricotta cheese. This new habit is related to the need to satisfy the tastes of the modern consumers that prefer a product more soft, creamy, doughy and lightly smoked. These addition modify the structure of this dairy, because it becomes more tender and moist. These features, as underlined by the technicians, determine a less shelf-life, in fact, it is important to consume these ricottas quickly to avoid the formation of bad smells and of a chalky texture [30]. In general, it can be pointed out that in this way, the identity of the product losses its peculiarity, with the risk to standardize the inimitable alpine ricotta cheese, as Chiorpis et al. [13] always emphasized.

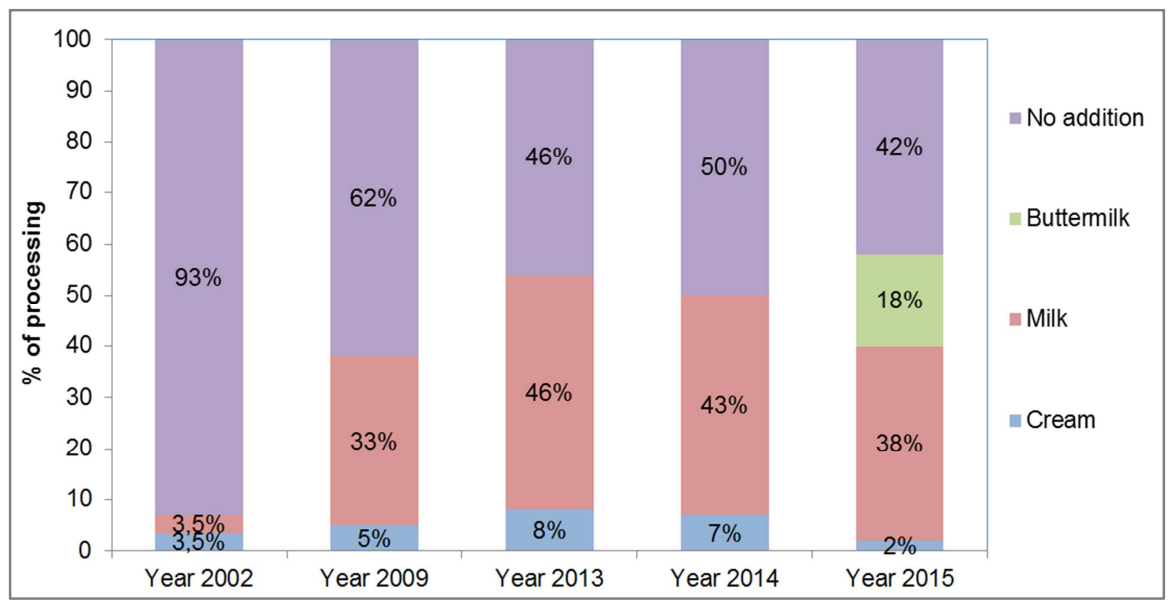

Figure 12. Technological addition of milk, cream or buttermilk to prepare the alpine ricotta cheese (comparison between years 2002-2009-2013-2014-2015) $(P<0.05)$. 
From the technological point of view, it was suggested to the cheesemakers to reduce the duration of the heating preferably at 30-40 minutes, in order to improve the rising of the albumin (principle protein in the whey, after the cheese production).

A correct salting step is very essential, because this practice is relevant since it enhances the expulsion of the whey and it prolong the preservability of the final product. Different are the methodology:

- dry salting: rubbing the surface of the ricotta with fine salt. Than stand it for a day, before smoking it.

- salting the whey: this modality consists in salting the whey before starting the processing. The procedure presents some defects, because it is expensive for the great amount of salt necessary and it is also not suitable for the further employment of this liquid for swine feeding.

- before the dripping of the canvas bags: the ricotta is put into tubs with sodium chloride and mixed. In this way a homogenous distribution of salt is guaranteed but there is the risk to ruin the texture of the final product.

Ponce De Leon-Gonzalez et al. [26] recovered that the final result isn't affected by the modality of salting.

The ending phase of the all processing is represented by the smoking. Usually it lasts $3 / 4$ days for soft ricottas, while it is prolonged till 10/15 days for harder ones. This duration is essential in order to enhance a gradual and uniform result, with abnormal colorations of the rind or too much intense taste.

\section{Conclusions}

Some reflections can be done about the perspective of qualitative improvement of this typical dairy products, that can, in a wider perspective, be an important train for the developing of all this marginal mountain area. In fact Alpine cheese and ricotta are emblematic and a symbol of the mountain of Friuli Venezia Giulia (Italy) [31]. The summer grazing of mountain pastures with lactating dairy cows is still a widespread practice in all the alpine regions and has positive repercussions on the quality image of many local dairy products [32]. Bovolenta [33] underlined the need to development models which examine the sustainability and multi-functionality of livestock production systems. The alpage can be considered a tool for improving the appeal of the landscape, the benefit of local cheese products and the diversification of this type of marginal agriculture in tourism [34]. This seasonal activity represents a reality with strong symbolisms and heritagization where nature and human presence join together in an intimate and harmonic way, creating attractiveness for the tourists, in a sort of "open air" museum [35].

In the future, typical dairy products will only be able to maintain their markets or develop them unless they are capable of holding their commercial ground and adapting to the market's needs and demands without losing their specificity, originality and authenticity (Bertoni et al., 2001). The new extraordinary success of niche food and the market demand for organic and traditional foods (for instance raw milk cheese of certified origin and zero-mileage food or farmers' market foodstuffs) are a symptom of a widespread consumer desire for better quality, which would be found in the peculiarities of local ones. Nowadays, the search for authenticity and preference for food with low ecologicalimpact, seem to find in the alpine environment a natural candidate for a repository of culture and bio-diversity [2]. In the specific context analyzed in the present paper, the efforts of Ersa recently were oriented also towards a quality liability system (quality mark: Aqua) which could guarantee artisan traits linked to the locality and cultural roots, as well as good quality features based on the standards required to satisfy consumer expectations [36]. Nevertheless, the unique features of these production systems have to be taken into account to avoid any excessive changes that could contribute to the loss of these 'inimitable treasures'. As observed by Bertoni et al. [21] it is otherwise important to evaluate carefully the controversy about whether and to what extent technology can be innovated. They affirmed that tradition does not exclude innovation, because the cultural heritage is not to be interpreted with the meaning of static and unchangeable. The techniques involved in traditional technology, which must be respected, can be modern. The most important objectives has to absolutely high safety and quality, that not always are related to typicality. The transformation of traditional Alpine cheese-making systems obviously requires a certain amount of standardization of traditional food processing, in order to offer local products on a wider market basis and in the logic of local/global dimension. It is interesting to notice, as suggested by Grasseni [2], that, in this way, autochthonous strategies for re-valuing intangible patrimony (local histories, material culture and landscapes) are mobilized.

During the 14 years of technical assistance, the cheesemakers that participated to the experimental project reached important goals along all the productive pathway. This support was dedicated with particular care to encourage and to guide the new generations, on the way to make the best technical and management choices. Accompanying the young in this productive chain that involves the artisanal culture is of particular relevance. The most important issue was that diversity and rootedness could become a commodity and they were always suggested to pursue an economic efficiency and a high quality level of the products [36]. The further programs of Ersa are oriented to continue in this activity, that can be considered a "good practices" to be spread, in order to keep on following the development of this compartment.

\section{Acknowledgements}

The authors wants to thank all the cheesemakers that take part to the experimental project of technical assistance, during these fourteen years. 
Annex 2: Schedule for Alpine Ricotta Cheese Date of Collection:

General information

\begin{tabular}{|l|l|}
\hline Cheesemaker hut & \\
\hline Cheese maker & \\
\hline Type of boiler & \\
\hline Type of heating (wood or other sources) & \\
\hline
\end{tabular}

Whey

\begin{tabular}{|l|l|l|}
\hline Total amount of whey $(\mathrm{Kg})$ & \multicolumn{2}{|c|}{} \\
\hline Acidity & $\left({ }^{\circ} \mathrm{SH} / 50 \mathrm{ml}\right)$ & $(\mathrm{pH})$ \\
\cline { 3 - 3 } & & \\
\hline
\end{tabular}

Technology

Disacidification of the whey (Yes or No)

\begin{tabular}{|c|c|c|c|c|}
\hline \multirow{2}{*}{\multicolumn{2}{|c|}{ Addition }} & \multirow{2}{*}{ Type } & \multicolumn{2}{|l|}{ Dose } \\
\hline & & & $(\mathrm{g} / \mathrm{Kg})$ & $1 / \mathrm{Kg}$ \\
\hline \multicolumn{5}{|l|}{ Acidifier } \\
\hline \multicolumn{5}{|l|}{ rock salt } \\
\hline \multicolumn{5}{|l|}{ milk } \\
\hline \multicolumn{5}{|l|}{ cream } \\
\hline \multicolumn{5}{|l|}{ buttermilk } \\
\hline \multicolumn{5}{|l|}{ other } \\
\hline \multicolumn{2}{|c|}{ Operations in the boiler } & Start time & Duration (min) & Temperature $\left({ }^{\circ} \mathrm{C}\right)$ \\
\hline \multicolumn{5}{|c|}{ Beginning of the heating } \\
\hline \multirow{3}{*}{ Addition of } & rock salt & & & \\
\hline & milk/cream/buttermilk, other & & & \\
\hline & acidifier & & & \\
\hline \multicolumn{5}{|c|}{ End of the precipitation and extraction } \\
\hline \multicolumn{5}{|c|}{ Duration of the heating } \\
\hline \multicolumn{5}{|c|}{ Duration of the precipitation (outcrop) } \\
\hline \multicolumn{2}{|c|}{ Total duration of the processing } & & & \\
\hline
\end{tabular}

Final treatments

\begin{tabular}{|l|l|}
\hline Purging by gravity (hours) & \\
\hline Pressing (hours) & \\
\hline Dry curing (Yes or No) & \\
\hline Smoking phase & \\
\hline
\end{tabular}

\section{References}

[1] J. Forrest, "Alpine-cheese", available online at: http://www.seriouseats.com/2009/02/-101.html.

[2] C. Grasseni, "Re-inventing food: Alpine cheese in the age of global heritage", in Anthropology of food, August 2011 (available online at: http://aof.revues.org/6819).

[3] S. Rainis, S. R. S. Cividino, and F. Sulli, "Analysis of the criticizes for zootechnics development in a mountain area of Italy", in Journal of Life Science, Vol. 7, No. 8, 846-855, August 2013.

[4] FAO, "Restarting from Nature for the Agricultural Development, FAO Introduces a New model of Agricultural Development to Produce More with Less", 2011, available on line at: http://www.fao.org/news/story/it/item/80136/icode/.

[5] Chiorpis G., and Rainis S., "L'assistenza tecnica dell'ERSA negli alpeggi del Friuli Venezia Giulia: tredici stagioni tra sperimentazione e tradizione" in Notiziario Ersa, pp. 15-23, February 2014.
[6] J. Meier, "What is alpine cheese" available online at: http://cheese.about.com/od/cheese_varieties/fl/What-isAlpine-Cheese.htm, 2016.

[7] J. Hazard, “Alpine cheeses", available online at: http://culturecheesemag.com/cheese-iq/alpine-cheeses Style Highlight: Alpine Cheeses, 2013.

[8] Istat. $6^{\circ}$ censimento generale dell'agricoltura in Friuli Venezia Giulia. Dati definitivi. Regione Autonoma del Friuli Venezia Giulia, July 2013. Available online at: http://www.regione.fvg.it/rafvg/cms/RAFVG/GEN/statistica/.

[9] O. Guneser, Y. K. Yuceer, "Characterization of aroma-active compounds, chemical and sensory properties of acidcoagulated cheese: Circassian cheese International", in Journal of Dairy Technology, Vol. 64, Issue 4, pp. 517-525, August 2011.

[10] V. Bottazzi, "Microbiologia e biotecnologia lattiero-casearia". Il Sole 24 Ore Edagricole, Bologna, 1993.

[11] O. Salvadori del Prato, "Trattato di Tecnologia Casearia". Edagricole, Bologna, 1998.

[12] S. Gunasekaran, and M. Mehmet Ak," Cheese Rheology and Texture", CrC Press, December 2002. 
[13] Chiorpis G., Pittino E., and S. Rainis, “Assistenza lattierocasearia in malga, i nuovi orizzonti del 2014", in Notiziario Ersa, pp. 43-49, December 2015.

[14] J. A. Lucey, M. E. Johnson, and D.S. Horne, "Invited Review: Perspectives on the Basis of the Rheology and Texture Properties of Cheese", in Journal of Dairy Science, Vol. 86, Issue 9, pp. 2725-2743, September 2003.

[15] J. B. Coulon, A. Delacroix-Buchet, B. Martin, and A. Pirisi, "Relationships between ruminant management and sensory characteristics of cheeses: a review", in Lait, Dairy science technology, Vol.84, n³, pp. 221-241, May-June 2004.

[16] B. Martin, I. Verdier-Metz, S. Buchin, C. Hurtaud, and J. -B. Coulon, "How do the nature of forages and pasture diversity influence the sensory quality of dairy livestock products?", in Animal Science, Vol. 81, Issue 02, pp 205-212, October 2005.

[17] S. Bovolenta, "Il pascolo alpino come strumento di valorizzazione del territorio e di qualificazione dei prodotti caseari", in Agribusiness Paesaggio \& Ambiente - Vol. 4, $\mathrm{n}^{\circ} 3$, December 2000.

[18] S. Dovier, R. Valusso, M. Morgante, A. Sepulcri, and S. Bovolenta, "Quality differences in cheeses produced by lowland and highland units of the Alpine transhumant system”, in Ital. J. Anim. Sci. Vol.4 (Suppl. 2), January 2010.

[19] M. Collomb, U. Butikofer, R. Siebera, B. Jeangrosb, and J.-O. Bosseta, "Correlation between fatty acids in cows' milk fat produced in the Lowlands, Mountains and Highlands of Switzerland and botanical composition of the fodder", in International Dairy Journal, Vol. 12, pp. 661-666, December 2002.

[20] G. Tornambè, A. Lucas, I. Verdier-Metz, S. Hulin, C. Agabriel, and B. Martin, "Effect of production systems on sensory characteristics of PDO Cantal cheese", in Ital. J. Anim. Sci., 4 (Suppl. 2) pp. 248-250, 2005.

[21] G. Bertoni, L. Calamari, and M. G. Maianti, "Producing specific milks for specialty cheeses", in Proceedings of the Nutrition Society Animal Nutrition and Metabolism Group Symposium on "Quality inputs for quality foods", Vol. 60 (2), pp. 231-46, May 2001.

[22] C. Agabriel, B. Martin, C. Sibra, J. C. Bonnefoy, M. C. Montel, R. Didienne, and S. Hulin, "Effect of dairy production systems on the sensory characteristics of Cantal cheeses: A plant scale study". Anim. Res., Vol. 53, pp. 221234, January 2004.

[23] G. Chiopris, D. Pasut, E. Pittino, and M. Sanna, "Il monitoraggio degli alpeggi per lo sviluppo dell'alpicoltura in Friuli Venezia Giulia, Linee guida per la gestione delle malghe”. Ersa Eds., 2014.

[24] E. Franciosi, I. Carafa, T. Nardin, S. Schiavon, E. Poznanski, A. Cavazza, R. Larcher, and K. M. Tuohy, "Biodiversity and $\gamma$-Aminobutyric Acid Production by Lactic Acid Bacteria Isolated from Traditional Alpine Raw Cow's Milk Cheeses", in BioMed Research International, Vol. 2015, 2015.
[25] E. Schornsteiner, E. Mann, O. Bereuter, M. Wagner, and S. Schmitz-Esser, "Cultivation-independent analysis of microbial communities on Austrian raw milk hard cheese rinds", in International Journal of Food Microbiology Volume 180, pp. 88-97, June 2014.

[26] L. Ponce De Leon-Gonzalez, W.L. Wendorff, B.H. Ingham, J. J. Jaeggi, and K. B. Houck, "Influence of Salting Procedure on the Composition of Muenster-Type Cheese", in Journal of dairy science, Vol. 83, Issue 6, pp. 1396-1401, June 2000.

[27] R. C. Lawrence, L. K. Creamer, and J. Gilles, J., "Texture development during cheese ripening", in J. Dairy Sci. Symposium: Cheese Ripening Technology, Vol. 70, n 8 , pp. 1748-1760, August 1987.

[28] R. A. Wilbey, J. E. Scott, and R. K. Robinson, "Cheesemaking Practice". Springer US, 3rd ed., 1998.

[29] E. Sorrentino, G. Tipaldi, G. Pannella, M. La Fianza, P. Succi, and P. Tremonte, "Influence of ripening conditions on Scamorza cheese quality", in Int. J. Agric. \& Biol. Eng.. Vol. $6 \mathrm{n}^{\circ} .3 / 71,2013$ available online at: http://www.ijabe.org.

[30] G. Hough, M. L. Puglieso, R. Sanchez, and O. Mendes da Silva, "Sensory and Microbiological Shelf-Life of a Commercial Ricotta Cheese", in Journal of Dairy Science, Vol. 82, Issue 3, pp. 454-459, March 1999.

[31] S. Rainis, F. Sulli, S. R. S. Cividino, and E. Cossio, "The impact on landscape, environmental and society of new productive chains in a mountain area: strategies, analysis and possibilities of development", in Journal of Agricultural Engineering, vol. 43, $\mathrm{n}^{\circ} 1$ :e2, May 2012.

[32] M. Mrad, E. Sturaro, G. Cocca, and M. Ramanzin, "The alpine summer pastures in the Veneto Region: management systems", in Proc. 18th Nat. Congr. ASPA, Palermo (Italy), Ital. J. Anim. Sci. vol. 8 (Suppl. 2), pp. 313-315, 2009, available online at: http://www.aspajournal.it/index.php/ijas/article/view/ijas.2009 .s2.313/427.

[33] S. Bovolenta, A. Romanzin, M. Corazzin, M. Spanghero, E. Aprea, F. Gasperi, and E. Piasentier, "Volatile compounds and sensory properties of Montasio cheese made from the milk of Simmental cows grazing on alpine pastures", in J Dairy Sci., Vol. 97(12), pp. 7373-85, December 2014.

[34] A. M. Hjalager, "Agricultural diversification into tourism: evidence of European Community development programme", in Tourism management, Vol. 17 (2), pp. 103-111, March 1996.

[35] M. Corti, "Le valenze turistiche ed educative del sistema delle alpi pascolive: indagine sugli eventi turistici sul tema dell'alpeggio"in Alpeggi - Quaderni Sozooalp. 1, pp. 53-89, May 2004.

[36] L. Berozzi, and G. Panari, "Cheeses with Appellation d'Origine Controlee (AOC): factors that affect quality", in Proceedings of the International Dairy Federation Seminar on Cheese Ripening, International Dairy journal, Vol. 3, pp. 297$312,1993$. 